\title{
Establishment of an in vivo model facilitates B2 receptor protein maturation and heterodimerization
}

\author{
Joshua Abd Alla, ${ }^{a}$ Armin Pohl, ${ }^{a}$ Kristin Reeck, ${ }^{b}$ Thomas Streichert ${ }^{b}$ and \\ Ursula Quitterer*a
}

Received 28th October 2009, Accepted 11th February 2010

First published as an Advance Article on the web 15th March 2010

DOI: $10.1039 / \mathbf{b 9 2 2 5 9 2 g}$

In individuals with diverse cardiovascular risk factors, signalling stimulated by the $\mathrm{AT}_{1}$ receptor for the vasopressor angiotensin II is sensitized by heterodimerization with the receptor for the vasodepressor bradykinin, $\mathrm{B}_{2}$. Signal sensitization and receptor heterodimerization rely on efficient maturation of the $\mathrm{B}_{2}$ receptor protein. To assess functional features of that important cardiovascular receptor system, we established an in vivo model by using immunodeficient NOD.Scid mice for the expansion of transfected cells under physiological conditions. Compared to cultivated cells, the in vivo model strongly facilitated $\mathrm{B}_{2}$ receptor maturation and heterodimerization. To elucidate the mechanisms underlying the enhancement of $\mathrm{B}_{2}$ receptor protein maturation under in vivo conditions, we performed microarray gene expression profiling. Microarray analysis revealed a more than 1.7-fold up-regulation of the chaperone calreticulin upon in vivo cell expansion whereas other important members of the general chaperone system were only marginally altered. Down regulation of calreticulin expression by RNA interference confirmed the importance of calreticulin for efficient $\mathrm{B}_{2}$ receptor maturation under in vivo conditions. Receptor proteins synthesized in the Nod.Scid cell expansion model were functionally active and sensitive to drug treatment as exemplified by treatment with the $\mathrm{AT}_{1}$-specific antagonist losartan. Thus, we established a model system that can be used to analyze functional features of proteins in vivo by expanding transfected cells in immunodeficient NOD.Scid mice.

\section{Introduction}

The major receptor for the vasoactive peptide hormone angiotensin II, $\mathrm{AT}_{1}$, exerts an indispensable physiological role in regulating vascular tone, ion and water homeostasis. Apart from the important physiological role, the pathogenesis of many cardiovascular disorders is characterized by a dysregulation of the vital angiotensin II $\mathrm{AT}_{1}$ receptor

\footnotetext{
${ }^{a}$ Molecular Pharmacology Unit, Swiss Federal Institute of Technology and University of Zurich, Winterthurerstrasse 190, CH-8057 Zurich, Switzerland.E-mail: ursula.quitterer@pharma.ethz.ch; Fax: + 41446356881

${ }^{b}$ Department of Clinical Chemistry/Central Laboratories, University Medical Center Hamburg-Eppendorf, Martinistrasse 52,

D-20246 Hamburg, Germany
}

system leading to an exaggerated angiotensin II response. ${ }^{1}$ Cellular mechanisms accounting for the hyperactivity of the angiotensin II system are therefore a major focus of research aimed to improve strategies for the treatment of cardiovascular disease.

Interaction of the bradykinin $\mathrm{B}_{2}$ receptor with the angiotensin $\mathrm{II}_{\mathrm{AT}}$ receptor occurs in vivo and may contribute to the hyperactivity of $\mathrm{AT}_{1}$-stimulated signal pathways under pathological conditions of cardiovascular disorders. ${ }^{2-5}$ Signal enhancement of the $\mathrm{AT}_{1}$ receptor by the $\mathrm{B}_{2}$ receptor relies on the formation of $\mathrm{AT}_{1} / \mathrm{B}_{2}$ receptor heterodimers, which requires disulfide-bond formation. ${ }^{3,4}$ The covalent association of $\mathrm{AT}_{1}$ and $\mathrm{B}_{2}$ receptors seems to account for the enhanced G-protein activation of $\mathrm{AT}_{1} / \mathrm{B}_{2}$ heterodimers relative to dissociable receptors because covalently stabilized receptors

\section{Insight, innovation, integration}

The $\mathrm{AT}_{1}$ receptor for the vasopressor angiotensin II is involved in the pathophysiology of hypertension and cardiovascular disorders. Under various in vivo conditions, the $\mathrm{AT}_{1}$ response is sensitized by heterodimerization with the $\mathrm{B}_{2}$ receptor. To analyze functional features of that important cardiovascular receptor system, the study established a novel model that applies immunodeficient Nod.Scid mice for expansion of cultured cells in vivo. Compared to conventional cell culture conditions, receptor protein maturation and heterodimerization were strongly facilitated by the novel model. In search for specific features of the system, microarray gene expression profiling revealed fine-tuned alterations of the general chaperone system that accounted for enhanced protein maturation and function in the novel cell expansion model. 
constitute a cellular platform that is kinetically favoured to interact with and activate heterotrimeric G-proteins. ${ }^{6,7}$ In agreement with this concept, signal enhancement of $\mathrm{AT}_{1}$ by the $\mathrm{B}_{2}$ receptor does not require the binding of bradykinin to $\mathrm{B}_{2}$ because a mutated $\mathrm{B}_{2}$ receptor with a $\sim 700$-fold reduced affinity for bradykinin is still capable of enhancing $\mathrm{AT}_{1}$ receptor-stimulated G-protein activation and signalling. ${ }^{3}$ Likewise, a $\mathrm{B}_{2}$ specific antagonist did not interfere with the angiotensin II-mediated activation of $\mathrm{AT}_{1} / \mathrm{B}_{2}$ receptor heterodimers. ${ }^{4}$ In contrast, a $\mathrm{B}_{2}$ receptor mutant deficient in G-protein activation did not enhance $\mathrm{AT}_{1}$ receptor-stimulated signalling. ${ }^{3}$ These findings strongly suggest that the intracellular receptor interface of $\mathrm{B}_{2}$ contacting the G-protein is important for the signal enhancement of $\mathrm{AT}_{1}$.

In addition to signal enhancement, $\mathrm{AT}_{1} / \mathrm{B}_{2}$ heterodimerization also alters the pathway of receptor internalization: The dynamin-independent internalization of individual $\mathrm{AT}_{1}$ and $\mathrm{B}_{2}$ receptors is switched to a dynamin-dependent internalization pathway upon $\mathrm{AT}_{1} / \mathrm{B}_{2}$ heterodimerization. ${ }^{3}$ Together these data point to conformational changes of the intracellular receptor interface upon heterodimerization, which may be responsible for the specific features of $\mathrm{AT}_{1} / \mathrm{B}_{2}$ heterodimers distinguishing receptor (hetero-)dimers from dissociable receptors. ${ }^{6,7}$

The specific characteristics of $\mathrm{AT}_{1} / \mathrm{B}_{2}$ receptor heterodimers were mainly deduced from receptors expressed under native conditions. $^{2-5}$ In contrast to native conditions, receptors synthesized from transfected genes often contain large quantities of immature protein prone to aggregation because the endogenous chaperones assisting protein folding may be limiting. ${ }^{8,9}$ To further analyze the functional features of $\mathrm{AT}_{1} / \mathrm{B}_{2}$ receptor heterodimers and their potential (patho-) physiological role, we established a novel model that recapitulates protein folding under in vivo conditions by expanding cultured cells in immunodeficient NOD.Scid mice.

\section{Materials and methods}

\section{Cultivation of cells and cell transfection}

HEK293 cells were routinely grown in DMEM $(450 \mathrm{mg} / \mathrm{dl}$ glucose) supplemented with $10 \%(\mathrm{v} / \mathrm{v}) \mathrm{FCS}$, and kept in a humidified $7.5 \% \mathrm{CO}_{2} / 92.5 \%$ air atmosphere at $37{ }^{\circ} \mathrm{C}$ unless otherwise indicated. Cells were transfected with Lipofectamine Plus (Invitrogen). Plasmids encoding the human $\mathrm{B}_{2}$ and $\mathrm{AT}_{1}$ receptor under control of the CMV promoter (pcDNA3, Invitrogen) were used to generate clonal cell lines with stable expression. To down regulate calreticulin expression by RNA interference (RNAi), replated NOD.Scid-expanded HEK293 cells were transfected with stealth $\mathrm{RNAi}^{10}$ targeting the coding sequence of the human calreticulin cDNA (nucleotides 59-83, RNAi-Calreticulin 1; nucleotides 320-344, RNAi-Calreticulin2). ${ }^{10}$ Down regulation of calreticulin was assessed by immunoblotting $40 \mathrm{~h}$ after transfection. For RNA interference studies under in vivo conditions, cell clones with RNA polymerase II promoterdriven expression of a control micro-RNA or a micro-RNA targeting calreticulin (nucleotides 324-344) were expanded in NOD.Scid mice. ${ }^{11}$

\section{Membrane preparation}

Membranes of in vitro cultivated or in vivo expanded HEK293 cells were prepared by sucrose density gradient centrifugation as described. ${ }^{3}$ Briefly, the crude membrane pellet of in vitro cultivated or in vivo expanded cells was prepared in $20 \mathrm{mM}$ Hepes, pH 7.4 containing $1 \mathrm{mM}$ phenylmethylsulfonyl fluoride, $2 \mu \mathrm{M}$ enalaprilate, $2 \mu \mathrm{M}$ leupeptin, $1 \mathrm{mM}$ bacitracin, $1 \mu \mathrm{M}$ E64 and $1 \mathrm{mM}$ phosphoramidon, layered onto a gradient composed of $10-45 \%(\mathrm{w} / \mathrm{v})$ sucrose and centrifuged $\left(100000 \times \mathrm{g}, 4{ }^{\circ} \mathrm{C}, 4 \mathrm{~h}\right)$. The membrane fraction was collected, diluted to a protein concentration of $1 \mathrm{mg} \mathrm{ml}^{-1}$ and stored at $-80{ }^{\circ} \mathrm{C}$ for further use. Receptor-enriched membranes contained usually $\sim 0.5-1 \mathrm{pmol} \mathrm{B}_{2}$ receptor $/ \mathrm{mg}$ protein unless otherwise indicated.

\section{Antibodies used for immunoblotting and immunofluorescence}

The following antibodies were used for immunoblotting, receptor immunoaffinity enrichment and immunofluorescence: affinity-purified rabbit/rat anti- $\mathrm{B}_{2}$ receptor antibodies (raised against an antigen corresponding to positions 28-60 of the human $\mathrm{B}_{2}$ receptor sequence); affinity-purified rabbit/rat anti- $\mathrm{B}_{2}$ receptor antibodies (raised against an antigen corresponding to positions $356-391$ of the human $\mathrm{B}_{2}$ receptor sequence); affinity-purified rabbit/rat anti- $\mathrm{AT}_{1}$ receptor antibodies (raised against an antigen corresponding to positions 306-359 of the human $\mathrm{AT}_{1}$ receptor sequence); affinity-purified rabbit anti- $\mathrm{AT}_{2}$ receptor antibodies (raised against an antigen corresponding to positions 320-349 of the human $\mathrm{AT}_{2}$ receptor sequence). Specificity and cross-reactivity of the resulting antisera with the respective protein was routinely monitored by immunoblotting and immunofluorescence. All antibodies were characterized in previous studies. ${ }^{3-6,11,12}$

\section{Protein detection in immunoblot and co-enrichment of receptors}

Immunoblotting was performed with membranes prepared by sucrose density gradient centrifugation as described above followed by partial enrichment. ${ }^{3}$ Proteins were dissolved in SDS-sample buffer containing $2 \%$ SDS, $5 \% \beta$-mercaptoethanol and $6 \mathrm{M}$ urea for $30 \mathrm{~min}$ at room temperature. Protein samples were separated by SDS-PAGE under reducing conditions and supplemented with urea followed by transfer to PVDF membranes. Affinity-purified antibodies or $\mathrm{F}(\mathrm{ab})_{2}$ fragments of the respective antibodies pre-absorbed to human proteins were used for detection of $\mathrm{B}_{2}$ or $\mathrm{AT}_{1}$ receptors. Bound antibody was visualized by pre-absorbed $\mathrm{F}(\mathrm{ab})_{2}$ fragments of enzyme-coupled secondary antibodies or by enzyme-coupled Protein A followed by enhanced chemiluminescence detection (ECL plus).

For co-enrichment of $\mathrm{AT}_{1}$ and $\mathrm{B}_{2}$ receptors, membranes of explanted HEK cells were solubilized with RIPA buffer (including protease inhibitor cocktail), and subjected to immunoaffinity chromatography by anti- $\mathrm{AT}_{1}$ receptor antibodies using $0.1 \mathrm{ml}$ immunoaffinity matrix (Affigel 10; $15 \mathrm{mg}$ affinity-purified antibodies per $\mathrm{ml}$ gel). After extensive washing, proteins were eluted with $0.2 \mathrm{M}$ glycine, $\mathrm{pH} 2.5$, neutralized, desalted, delipidated and precipitated. ${ }^{3}$ Eluted proteins were dissolved and separated by urea-containing SDS-PAGE under reducing conditions. Enriched $\mathrm{AT}_{1}$ and 
co-enriched $\mathrm{B}_{2}$ receptors were identified in immunoblot with the respective anti-receptor antibodies.

\section{Immunofluorescence}

Detection of receptors on NOD.Scid-expanded HEK293 cells was performed with dispersed cells expanded in NOD.Scid mice or cryosections $(10 \mu \mathrm{m})$ of the isolated and frozen HEK cell pellet obtained from 3 months-old NOD.Scid mice three weeks after subcutaneous injection of $6-8 \times 10^{6}$ HEK293 cells $/ 200 \mu$ l. For co-localization of $\mathrm{AT}_{1}$ and $\mathrm{B}_{2}$, affinitypurified rat anti- $\mathrm{AT}_{1}$ receptor antibodies and rabbit anti- $\mathrm{B}_{2}$ receptor antibodies were applied (dilution 1:4000), followed by secondary antibodies labeled with Alexa Fluor 488 and Alexa Fluor 546, respectively (Molecular Probes; dilution 1:5000). Sections and cells were imaged with a Leica DMI6000 and a confocal laser microscope (Leica TCS SPE).

\section{Microarray gene expression profiling}

For microarray gene expression analysis, replated NOD.Scidexpanded HEK 293 cells, and in vitro cultivated HEK293 cells (cultivated in DMEM supplemented with $10 \%$ FCS, and $450 \mathrm{mg} / \mathrm{dl}$ or $100 \mathrm{mg} / \mathrm{dl}$ glucose as indicated) were used. Total RNA was isolated with the RNeasy Mini kit (Qiagen). Procedures for cDNA synthesis, labeling and hybridization were carried out according to the protocol of the manufacturer (Affymetrix GeneChip Expression Analysis Technical Manual; Rev. 5). For hybridization, $15 \mu \mathrm{g}$ of fragmented cRNA were incubated with the chip (Affymetrix GeneChip Human genome U133 Plus 2.0 Array) in $200 \mu$ of hybridization solution in a Hybridization Oven 640 (Affymetrix) at $45^{\circ} \mathrm{C}$ for $16 \mathrm{~h}$. GeneChips were then washed and stained using the Affymetrix Fluidics Station 450. Microarrays were scanned with the Affymetrix GeneChip Scanner 7G, and the signals were processed using GCOS (v. 1.4, Affymetrix). Gene expression data are available at NCBI GEO database accession no GSE15575 and GSE18739.

\section{In vivo expansion of HEK293 cells in NOD.Scid mice}

NOD.Scid mice (age 3 months) were injected subcutaneously with $6-8 \times 10^{6}$ cells $/ 200 \mu \mathrm{l}$ PBS. For expansion in NOD.Scid mice, HEK 293 cell clones were used stably expressing the $B_{2}$ receptor (HEK-B2) or co-expressing $\mathrm{AT}_{1}$ and $\mathrm{B}_{2}$ receptors (HEK-AT1/B2). Three weeks after the injection, mice were anesthetized, perfused intracardially with physiological phosphate buffer, pH 7.2, and the expanded HEK293 cell pellet was isolated and processed for further use. As indicated, NOD.Scid mice were treated with or without the $\mathrm{AT}_{1}$-specific antagonist, losartan, for three weeks $\left(30 \mathrm{mg} \mathrm{kg}^{-1}\right.$ supplied in drinking water).

Quantification of cell-surface $B_{2}$ receptors was performed on dispersed, in vivo expanded HEK cells with $50 \mathrm{nM}$ of $\left[{ }^{125} \mathrm{I}\right]$-labeled $\mathrm{F}(\mathrm{ab})_{2}$ fragments of affinity-purified $\mathrm{B}_{2}$ receptorspecific antibodies $(\sim 1 \mu \mathrm{Ci})$ similarly as described. ${ }^{11}$

\section{Animal experiments}

All animal experiments were reviewed and approved by the committees on animal research at the University of Hamburg and Zurich, and were conducted in accordance with the NIH guidelines.

\section{Statistics}

Unless otherwise stated, data are expressed as mean \pm S.E. To determine significance between two groups, we made comparisons using the unpaired, two-tailed Student's t-test. $P$ values $<0.05$ were considered significant.

\section{Results}

\section{Maturation of the bradykinin $B_{2}$ receptor protein in cultivated} HEK293 cells depends on cell and culture conditions

$\mathrm{AT}_{1} / \mathrm{B}_{2}$ receptor heterodimerization relies on efficient maturation of the $\mathrm{B}_{2}$ receptor protein. ${ }^{10}$ Over-expressing cells often produce large amounts of immature protein because the endogenous pool of chaperones may be limiting. ${ }^{8,9}$ In agreement with those observations, HEK293 cells over-expressing the $\mathrm{B}_{2}$ receptor synthesized significant amounts of an immature $B_{2}$ receptor protein of $53 \pm 4 \mathrm{kDa}$ in addition to the mature protein of $67 \pm 5 \mathrm{kDa}$ when cultivated in a standard cell culture medium containing a glucose concentration of $450 \mathrm{mg} / \mathrm{dl}$ (Fig. 1(a), lane 1; and ref. 10).

Glucose is known to down regulate the expression of several chaperones. ${ }^{13}$ To enhance the maturation of the $\mathrm{B}_{2}$ protein, we applied a medium with a "physiological" (low) glucose concentration of $100 \mathrm{mg} / \mathrm{dl}$. Compared to high glucose, the low glucose medium led to the enhanced synthesis of the mature $\mathrm{B}_{2}$ receptor protein of $\sim 67 \mathrm{kDa}$ (Fig. 1(a), lane 2; and ref. 10). These observations show that $\mathrm{B}_{2}$ receptor protein maturation of in vitro cultivated cells is highly dependent on cell and culture conditions.

\section{Identification of glucose-sensitive members of the general chaperone system by microarray gene expression profiling}

To determine the impact of cell culture conditions on the general chaperone system of HEK293 cells, we performed microarray gene expression profiling of HEK293 cells cultivated in medium with high and low glucose, respectively. Microarray gene expression profiling revealed a strong up-regulation of the general chaperone system of HEK293 cells cultivated in low glucose medium relative to high glucose (Fig. 1(b) and ref. 10). The 14 glucose-sensitive members of the general chaperone system of HEK293 cells are depicted in Fig. 1(b).

Immunoblot analysis confirmed the increased expression of important members of the general chaperone system under low glucose as exemplified for GRP78 and calreticulin (Fig. 1(c)). As a control, $\beta$-actin expression levels were not significantly different (Fig. 1(b and c)). Thus, maturation of a prototypic membrane protein can be severely affected by the chosen glucose concentration of the culture medium because several members of the general chaperone system are highly glucose-sensitive.

\section{In vivo expansion of HEK293 cells in NOD.Scid mice restores an imbalanced chaperone system}

As demonstrated above with a prototypical membrane receptor, protein maturation can be extremely variable 
a

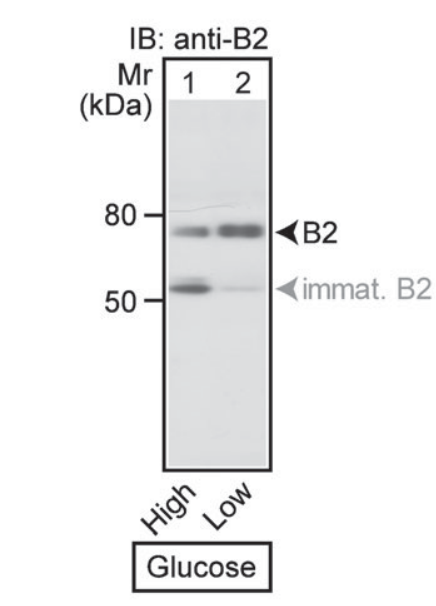

C
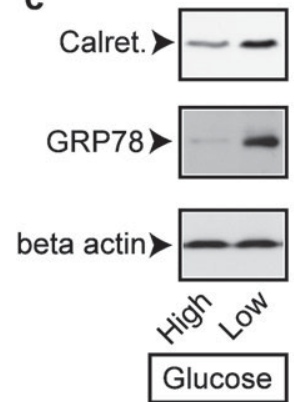

b

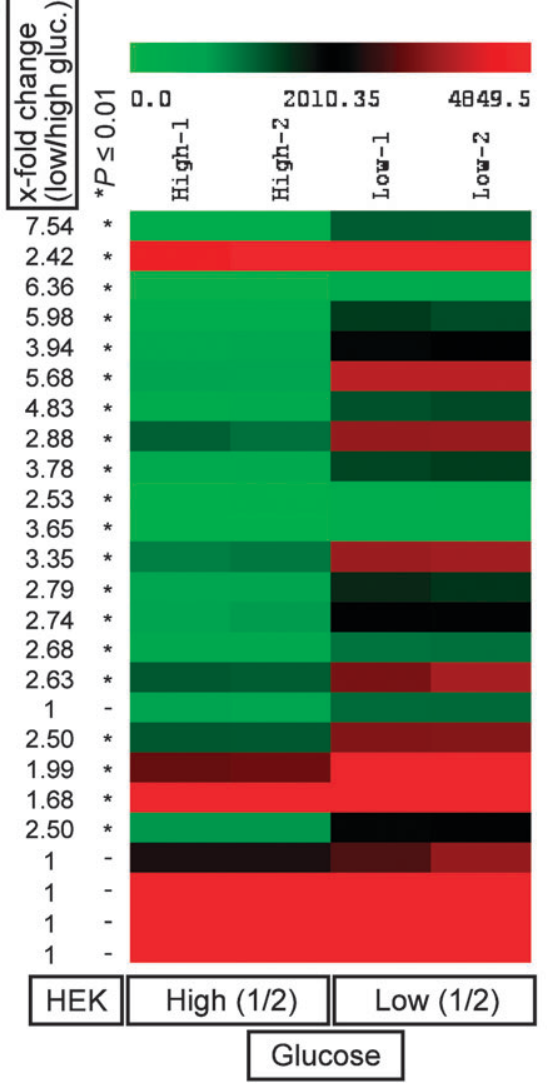

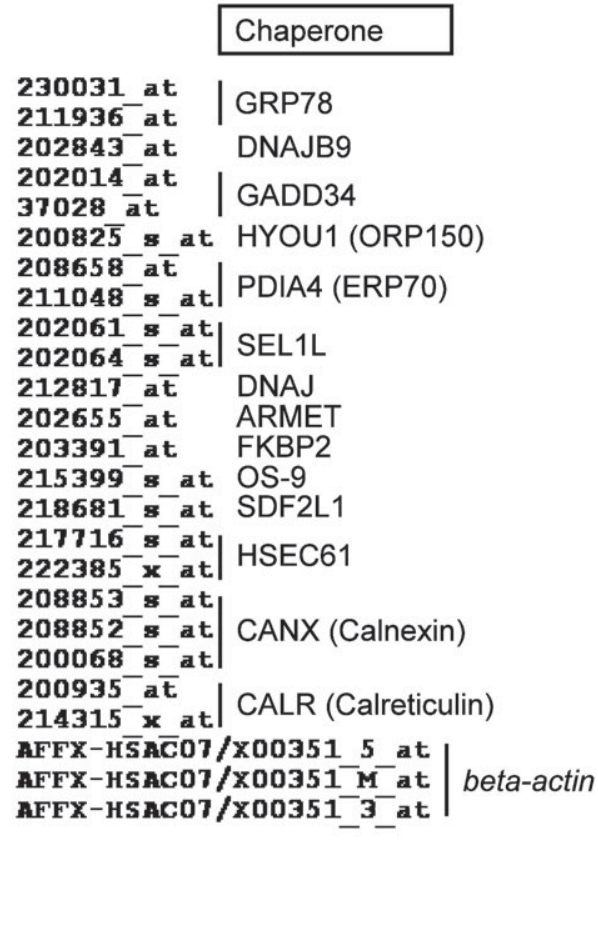

Fig. 1 Microarray gene expression profiling identifies glucose-sensitive chaperones of HEK293 cells. (a) Immunoblot detection of the $B_{2}$ receptor (IB: anti-B2) on enriched membranes of HEK293 cells (expression of $\sim 200 \mathrm{fmol} \mathrm{B} / 2 / \mathrm{mg}$ protein) cultivated in a medium with high (450 mg/dl) or low $(100 \mathrm{mg} / \mathrm{dl})$ glucose revealed the mature (B2) and immature $\mathrm{B}_{2}$ receptor protein (immat. B2). (b) Microarray gene expression profiling of HEK293 cells. Differentially expressed probe sets of low glucose-cultivated HEK293 cells relative to high glucose-cultivated HEK293 cells $(x$-fold change; low/high gluc.; ${ }^{*} P$ value $\left.\leq 0.01\right)$, ER localization and involvement in the general chaperone system are listed. If available, alternative probe sets of the differentially expressed chaperones are also shown. Normalized signal intensity values are presented as heat map. Probe sets of beta actin demonstrate integrity of biotin-labeled cRNAs used for gene chip hybridization ( $3^{\prime} / 5^{\prime}$ ratio: $\left.1.17-1.36\right)$. (c) Immunoblot analysis controlling the microarray data.

depending on the selected culture conditions. To analyze protein maturation in a more standardized environment, we established an in vivo model. To this end we used immunodeficient NOD.Scid mice for in vivo expansion of HEK293 cells. Cells were injected subcutaneously, and after three weeks, the expanded HEK293 cell pellet was isolated from NOD.Scid mice (Fig. 2(a)).

In contrast to conventional cell cultivation, in vivo expanded cells are exposed to a tightly controlled physiological environment. To validate the novel model, we analyzed the general chaperone system by microarray gene expression profiling. For our analysis, we selected those chaperones that were highly regulated under in vitro cell culture conditions (Fig. 2(b) versus Fig. 1(b)). Interestingly, the in vivo model showed only subtle alterations of the general chaperone system relative to in vitro cultured HEK293 cells (Fig. 2(b)). A significantly different expression was only detected for probe sets of four different chaperones, i.e. glucose-regulated protein (GRP78), protein disulfide isomerase (PDIA4), HSEC61 and calreticulin (Fig. 2(b)). With a more than 1.7-fold increased expression, calreticulin showed the strongest difference between in vivo and in vitro conditions. Thus, the in vivo expansion of cells in NOD.Scid mice apparently restored an imbalanced chaperone system without inducing a massive up-regulation of the entire protein folding machinery.

\section{Expansion of HEK293 cells in NOD.Scid mice facilitates $B_{2}$ receptor protein maturation}

The selective enhancement of calreticulin expression in the established model system was intriguing because calreticulin is known to be required for $\mathrm{B}_{2}$ receptor maturation, heterodimerization and function. ${ }^{10,14} \mathrm{We}$ therefore investigated whether $\mathrm{B}_{2}$ receptor protein maturation was enhanced upon in vivo cell expansion. HEK293 cell clones stably expressing the $\mathrm{B}_{2}$ receptor were implanted subcutaneously into NOD.Scid mice as detailed above. After three weeks, the expanded cell pellets were isolated. Immunofluorescence confirmed that the isolated cells consisted of expanded HEK293 cells because the $B_{2}$ receptor was only detected on expanded HEK-B2 cells stably expressing the $\mathrm{B}_{2}$ receptor whereas $B_{2}$ receptors were not detected on expanded control HEK-P3 cells lacking $B_{2}$ receptor expression (Fig. 3(a)). 

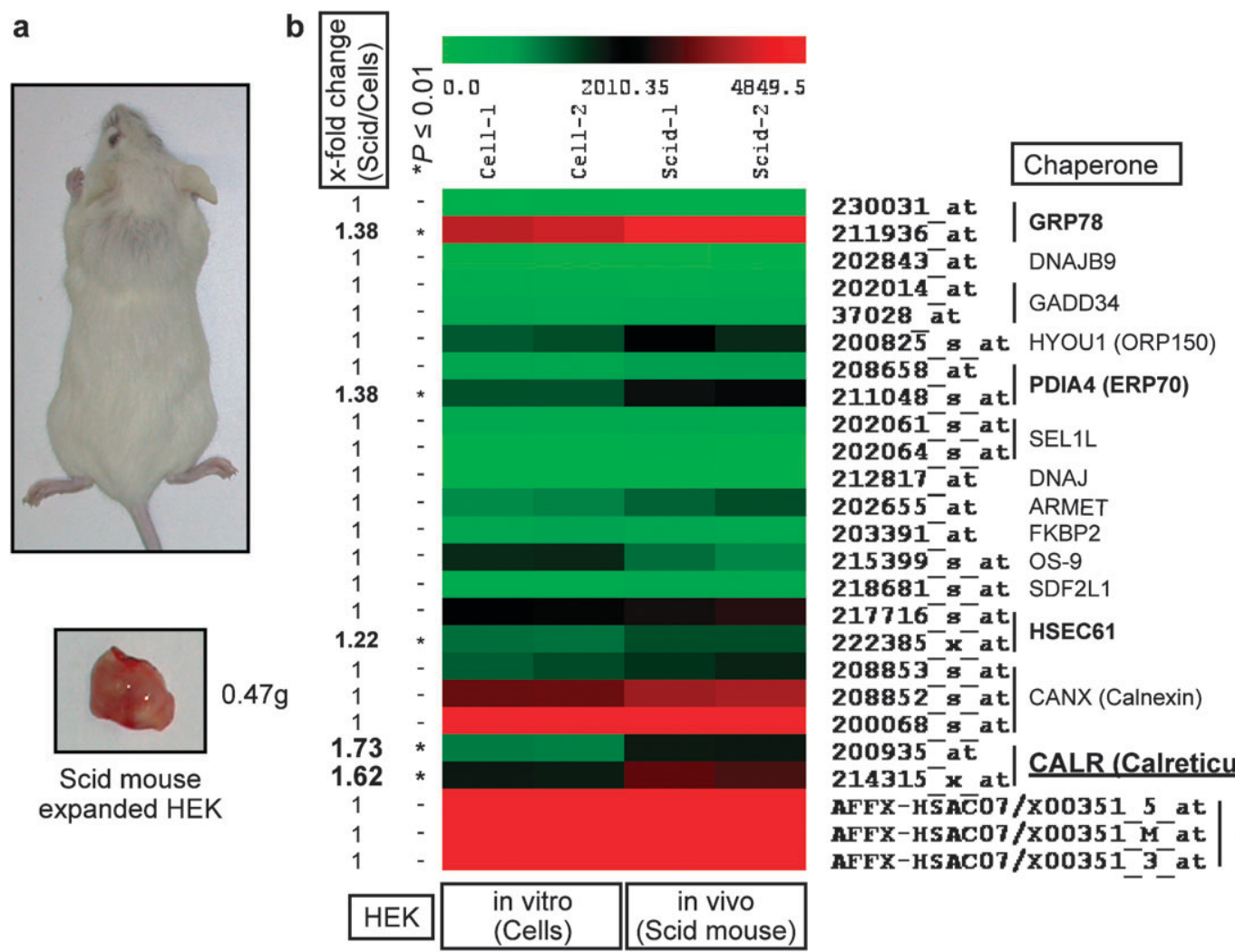

$208658^{-} \mathrm{at}$

211048- $\mathrm{s}$ at $\mid$ PDIA4 (ERP70)

$202061^{-} \mathrm{s}$ at

202064-s-at SEL1L

212817-at DNAJ

$202655^{-}$at $A R M E T$

203391-at FKBP2

$215399^{-} \mathrm{s}$ at OS-9

$218681^{-}$s at SDF2L1

$217716^{-}$s-at $\mid$HSEC61

$208853^{-} \mathrm{s}^{-} \mathrm{at}$

$208852^{-} \mathbf{s}^{-}$at CANX (Calnexin)

$200068^{-} \mathrm{s}-\mathrm{at}$

$200935^{-}$at

$214315^{-} \times$at CALR (Calreticulin)

AFFX-H $\bar{S} \mathbf{A C} 07 / \mathrm{X} 003515$ at

AFFX-HSAC07/X00351- M-at beta-actin

AFFX-HSAC07/X00351-3-at

\begin{tabular}{|c|c|c|}
\hline HEK & $\begin{array}{c}\text { in vitro } \\
\text { (Cells) }\end{array}$ & $\begin{array}{c}\text { in vivo } \\
\text { (Scid mouse) }\end{array}$ \\
\hline
\end{tabular}

Fig. 2 In vivo expansion of HEK293 cells in NOD.Scid mice restores an imbalanced chaperone system. (a) HEK293 cells were subcutaneously injected into immune-deficient NOD.Scid mice. After in vivo expansion for three weeks, mice were anesthetized (upper panel), and the expanded cell pellet was isolated (lower panel; Scid mouse-expanded HEK). (b) Microarray gene expression profiling of NOD.Scid-expanded (in vivo; Scid mouse), and in vitro cultivated clonal HEK 293 cells (in vitro, Cells; $450 \mathrm{mg} / \mathrm{dl}$ glucose). The heat map shows normalized signal intensity values of the glucose-sensitive chaperones identified in Fig. 1(b). The analysis identified differentially expressed probe sets of four different chaperones $\left({ }^{*} P\right.$ value $\left.\leq 0.01\right)$. Probe sets of beta actin demonstrate integrity of biotin-labeled cRNAs used for gene chip hybridization $\left(3^{\prime} / 5^{\prime}\right.$ ratio: $\left.1.23-1.28\right)$. The microarray data represent two biological replicates for each condition (GSE18739). Data shown are representative of three independent experiments performed with 2-3 mice each.

Next, we determined the $\mathrm{B}_{2}$ receptor in immunoblot. In agreement with the previous data ( $c f$. Fig. 1(a)), the $\mathrm{B}_{2}$ receptor of conventionally cultivated HEK293 cells kept in a high glucose medium appeared predominantly as an immature form of $53 \pm 4 \mathrm{kDa}$. In contrast, upon in vivo expansion in NOD.Scid mice, the $B_{2}$ receptor of HEK293 cells was synthesized as a mature form of $67 \pm 5 \mathrm{kDa}$ (Fig. 3(b)). Immunoblot detection of calreticulin confirmed the microarray data showing that the in vivo expansion of cells in NOD.Scid mice led to significantly increased calreticulin protein levels relative to in vitro cultivated HEK293 cells (Fig. 3(b)). For comparison, changes in GRP78 expression were only minor (Fig. 3(b)). As a control, maturation of the $\mathrm{B}_{2}$-related angiotensin II $\mathrm{AT}_{2}$ receptor protein was not different before and after in vivo expansion (Fig. 3(c)). Thus, the in vivo environment of NOD.Scid mice facilitated maturation of the $\mathrm{B}_{2}$ receptor protein.

\section{Involvement of calreticulin in $\mathrm{B}_{2}$ receptor maturation of in vivo expanded cells}

To analyze whether calreticulin was indeed involved in $\mathrm{B}_{2}$ receptor maturation, we down-regulated calreticulin expression of in vivo expanded and replated HEK cells by transfection of stealth RNAi. Down regulation of calreticulin by RNA interference was confirmed by immunoblot with calreticulin-specific antibodies (Fig. 4(a), left panel). As a control, transfection with an unrelated control RNAi duplex did not affect calreticulin protein levels (Fig. 4(a), left panel). Concomitant to the down-regulation of calreticulin, protein levels of the immature $B_{2}$ receptor form of $53 \pm 4 \mathrm{kDa}$ were strongly increased (Fig. 4(a), right panel).

Similar results were obtained by RNA interference studies under in vivo conditions by expanding two different cell clones with RNA polymerase II promoter-driven expression of a micro-RNA targeting calreticulin (Fig. 4(b)). Upon three weeks of expansion in NOD.Scid mice, micro-RNA expressing HEK cell clones targeting calreticulin by RNA interference showed a significant down regulation of calreticulin expression relative to cell clones expressing a control micro-RNA as assessed by immunoblotting (Fig. 4(b), left panels). In agreement with the involvement of calreticulin in $\mathrm{B}_{2}$ receptor maturation under in vivo conditions, protein levels of the immature $\mathrm{B}_{2}$ receptor form of $53 \pm 4 \mathrm{kDa}$ were significantly increased upon down regulation of calreticulin (Fig. 4(b), right panel). Together these experiments provide evidence that restoration of calreticulin expression contributed to the enhanced $\mathrm{B}_{2}$ receptor protein maturation of the novel in vivo model. 
a

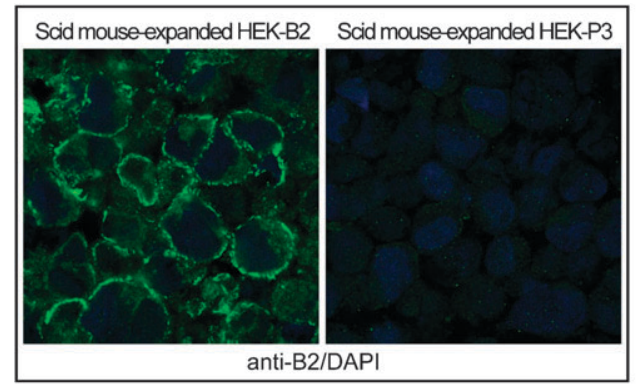

b

Scid mouse-expanded HEK HEK-B2

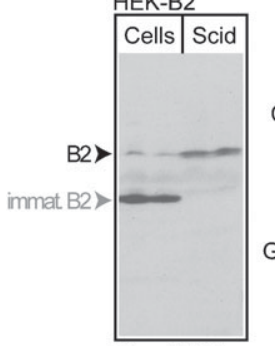

IB: anti-B2 c

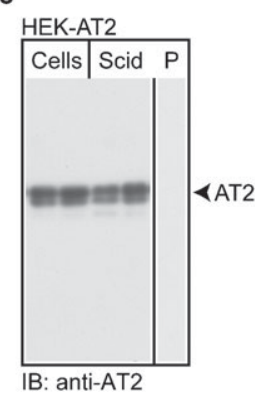

Fig. 3 Expansion of HEK293 cells in NOD.Scid mice facilitates $\mathbf{B}_{2}$ receptor protein maturation. (a) Immunofluorescence detection of the $\mathrm{B}_{2}$ receptor with anti- $\mathrm{B}_{2}$ receptor antibodies (anti-B2; cell nuclei were stained with DAPI) on a cryosection of a NOD.Scid-expanded HEK-B2 cell pellet (left panel; Scid mouse-expanded HEK-B2). As a control, the anti- $\mathrm{B}_{2}$ receptor antibodies did not interact with expanded HEK-P3 cells lacking $B_{2}$ receptor expression (right panel; Scid mouseexpanded HEK-P3), (original magnification, 630×). (b) In vivo expansion of two different $\mathrm{B}_{2}$ receptor expressing $\mathrm{HEK}-\mathrm{B}_{2}$ cell clones for three weeks in NOD.Scid mice induced the synthesis of the mature $\mathrm{B}_{2}$ receptor of $\sim 67 \mathrm{kDa}$ (lanes 3,4 ; Scid) whereas the immature $\sim 53 \mathrm{kDa} \mathrm{B}_{2}$ receptor (immat. B2) was the predominant form before in vivo expansion and cultivation in high glucose medium (lanes 1,2; Cells). The $\mathrm{B}_{2}$ receptor was detected on enriched membranes by immunoblot with $\mathrm{F}(\mathrm{ab})_{2}$ fragments of affinity-purified $\mathrm{B}_{2}$-specific antibodies pre-absorbed to human proteins (IB: anti-B2). Right panels: Calreticulin protein expression as determined in immunoblot with anti-calreticulin antibodies (IB: anti-Calret.) was significantly increased upon in vivo expansion of HEK-B2 cells in NOD.Scid mice (upper panel; "Scid" versus "Cells"). Immunoblot detection of GRP78 did not reveal a major difference between in vivo expanded relative to conventionally cultivated cells (lower panel). (c) As a control, protein levels and maturation of the related $\mathrm{AT}_{2}$ receptor were not different before and after in vivo expansion of two different HEK-AT2 cell clones in NOD.Scid mice as determined in immunoblot with $F(a b)_{2}$ fragments of affinity-purified anti- $\mathrm{AT}_{2}$ antibodies pre-absorbed to human proteins (IB: anti-AT2). In lane "P", anti-AT 2 antibodies pre-absorbed to the immunizing antigen were used as a control to confirm antibody specificity.

In vivo expansion of HEK293 cells in NOD.Scid mice enhances $A T_{1} / B_{2}$ receptor heterodimerization

Efficient maturation of the $\mathrm{B}_{2}$ receptor protein is required for heterodimerization with the $\mathrm{AT}_{1}$ receptor. ${ }^{10}$ To analyze whether the in vivo model also supported heterodimerization of the $\mathrm{B}_{2}$ receptor with the $\mathrm{AT}_{1}$ receptor, we expanded HEK-AT1/B2 cells co-expressing $\mathrm{AT}_{1}$ and $\mathrm{B}_{2}$ receptors in NOD.Scid mice. The expression of the $\mathrm{AT}_{1}$ and $\mathrm{B}_{2}$ receptor on in vivo expanded HEK cells was determined by immunofluorescence applying antibodies specifically crossreacting with the $\mathrm{AT}_{1}$ and $\mathrm{B}_{2}$ receptor, respectively. ${ }^{3-5}$ Immunofluorescence analysis demonstrated a high degree of co-localization of $\mathrm{AT}_{1}$ and $\mathrm{B}_{2}$ receptors on the cell membrane of in vivo expanded HEK-AT1/B2 cells (Fig. 5(a)).

To determine whether the co-localized receptors formed a direct protein interaction, we enriched the $\mathrm{AT}_{1}$ receptor with $\mathrm{AT}_{1}$-specific antibodies, and detected the co-enriched $\mathrm{B}_{2}$ receptor with $\mathrm{B}_{2}$-specific antibodies in immunoblot. As a control, efficient enrichment of $\mathrm{AT}_{1}$ was confirmed by immunoblotting with $\mathrm{AT}_{1}$-specific antibodies. Enrichment of $\mathrm{AT}_{1}$ receptors with $\mathrm{AT}_{1}$-specific antibodies and detection of co-enriched $\mathrm{B}_{2}$ receptors in immunoblot revealed the direct interaction of $\mathrm{AT}_{1}$ with $\mathrm{B}_{2}$ receptors on NOD.Scid-expanded HEK-AT1/B2 cells (Fig. 5(b)). Thus, the mature $\mathrm{B}_{2}$ receptor protein of in vivo expanded cells undergoes a direct interaction with the $\mathrm{AT}_{1}$ receptor, which is a characteristic feature of receptor hetero(di)merization. ${ }^{2-5,10}$

\section{Assessment of $\mathrm{AT}_{1} / \mathrm{B}_{2}$ receptor function in vivo by drug treatment with the $A T_{1}$-specific antagonist losartan}

Do the $\mathrm{AT}_{1} / \mathrm{B}_{2}$ receptor complexes of in vivo expanded HEK-AT1/B2 cells display functional features of $\mathrm{AT}_{1} / \mathrm{B}_{2}$ receptor heterodimers? The functional coupling of the in vivo synthesized heterodimers was analyzed by their sensitivity to stimulation with angiotensin II. Stimulation of $\mathrm{AT}_{1} / \mathrm{B}_{2}$ receptor heterodimers by angiotensin II induces receptor co-internalization and down regulation. ${ }^{3,15}$ To assess the stimulation of $\mathrm{AT}_{1} / \mathrm{B}_{2}$ receptor heterodimers in vivo, we determined the effect of circulating blood angiotensin II on $\mathrm{B}_{2}$ receptors associated with $\mathrm{AT}_{1}$ in $\mathrm{AT}_{1} / \mathrm{B}_{2}$ heterodimers relative to individual $B_{2}$ receptors. To this end, NOD.Scid mice were transplanted with HEK-AT1/B2 or HEK-B2 cells. After cell injection, mice were treated for three weeks with a standard dose of the $\mathrm{AT}_{1}$-specific antagonist, losartan (30 $\mathrm{mg} \mathrm{kg}^{-1}$, supplied in drinking water), which inhibits $\mathrm{AT}_{1}$ receptor-stimulated responses in mice. ${ }^{16}$ The number of cellular $\mathrm{B}_{2}$ receptors after three weeks of in vivo expansion was quantified with [ $\left.{ }^{125} \mathrm{I}\right]$-labeled $\mathrm{F}(\mathrm{ab})_{2}$ fragments of affinitypurified anti- $\mathrm{B}_{2}$ receptor antibodies. Losartan treatment of NOD.Scid mice induced a significant increase in the number of $\mathrm{B}_{2}$ receptors on expanded HEK-AT1/B2 cells relative to untreated mice (Fig. 6, columns 1, 2). For comparison, losartan treatment did not affect $\mathrm{B}_{2}$ receptor levels of NOD.Scid-expanded HEK-B2 cells expressing only $\mathrm{B}_{2}$ receptors (Fig. 6, columns 3, 4). As a control, in vivo expanded HEK-P3 cells without $\mathrm{B}_{2}$ receptor expression did not show a significant interaction with $\left[{ }^{125} \mathrm{I}\right]$-labeled anti-B $\mathrm{B}_{2}$ receptor antibodies (Fig. 6, columns 5, 6). Together these experiments are compatible with the notion that $\mathrm{B}_{2}$ receptors, which are part of functional $\mathrm{AT}_{1} / \mathrm{B}_{2}$ receptor heterodimers are internalized by circulating angiotensin II activating $\mathrm{AT}_{1}$. Vice versa, inhibition of $\mathrm{AT}_{1}$ by losartan could prevent $\mathrm{AT}_{1} / \mathrm{B}_{2}$ co-internalization as revealed by the increased $\mathrm{B}_{2}$ receptor number of $\mathrm{HEK}-\mathrm{AT} 1 / \mathrm{B} 2$ cells isolated from losartan-treated mice relative to untreated mice.

Altogether, the in vivo expansion of HEK cells in NOD.Scid mice restored an imbalance of the general chaperone system induced by conventional in vitro cell culture. As a consequence, 
a

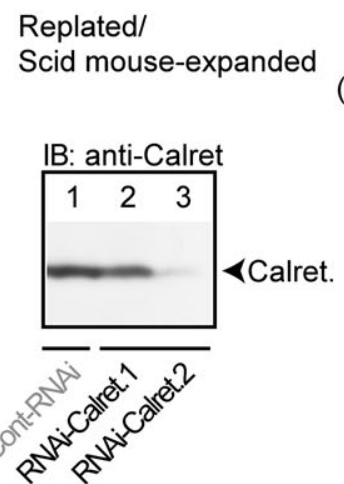

IB: anti-B2

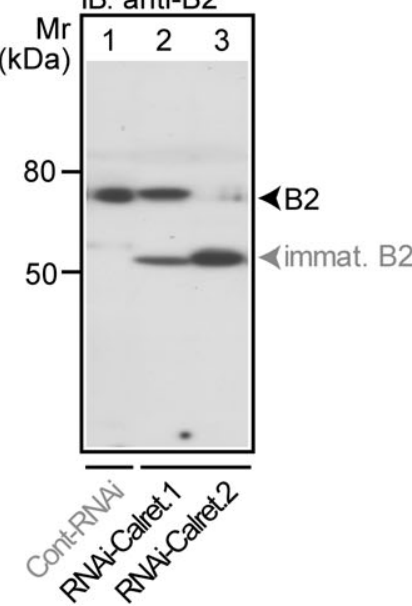

b
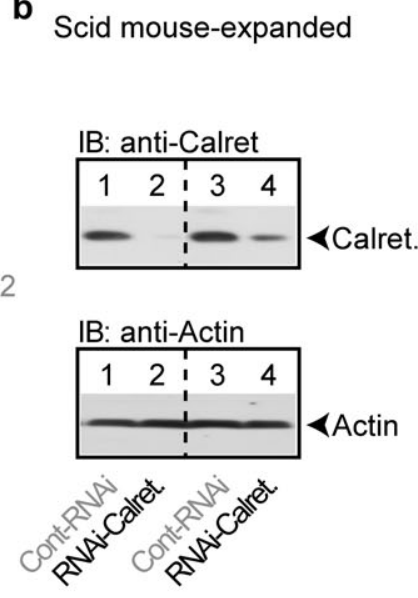

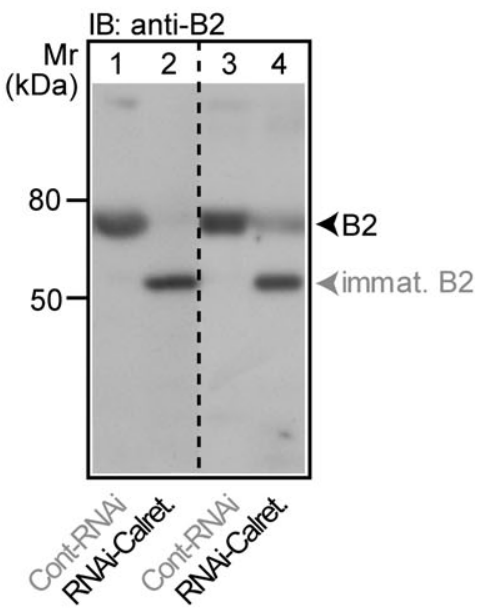

Fig. 4 Involvement of calreticulin in $\mathbf{B}_{2}$ receptor maturation of in vivo expanded cells. (a) Left panel: Immunoblot detection of calreticulin (IB: anti-Calret.) in replated, NOD.Scid-expanded HEK-B2 cells transfected with a control RNAi duplex (Cont-RNAi; lane 1) or RNAi duplexes targeting the coding sequence of calreticulin (RNAi-Calret.1/2; lanes 2,3) confirms the down regulation of calreticulin by RNA interference. Right panel: Immunoblot detection of the $\mathrm{B}_{2}$ receptor with $\mathrm{F}(\mathrm{ab})_{2}$ fragments of affinity-purified $\mathrm{B}_{2}$-specific antibodies pre-absorbed to human proteins (IB: anti-B2) on enriched membranes of in vivo expanded and replated HEK cells transfected with a control RNAi duplex (Cont-RNAi; lane 1) or RNAi duplexes targeting the coding sequence of calreticulin (RNAi-Calret.1/2; lanes 2,3). Upon down regulation of calreticulin, protein levels of the immature $\mathrm{B}_{2}$ receptor form of $\sim 53 \mathrm{kDa}$ (immat. B2) were strongly increased. (b) Similar results as in (a) were obtained under in vivo conditions with two different, NOD.Scid-expanded HEK-B2 cell clones expressing a control micro-RNA (Cont-RNAi; lanes 1,3), or a micro-RNA targeting the coding sequence of calreticulin (RNAi-Calret.; lanes 2,4). Immunoblots show detection of calreticulin (IB: anti-Calret.; upper panel-left), beta-actin (IB: anti-Actin; lower panel-left), and the $\mathrm{B}_{2}$ receptor (IB: anti-B2; right panel).

a Scid mouse-expanded HEK-AT1/B2

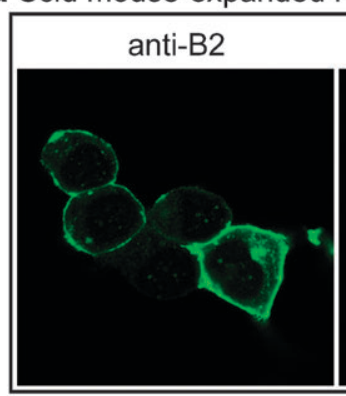

anti-AT1

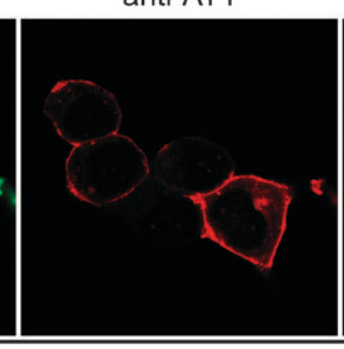

\section{Colocalization AT1/B2}

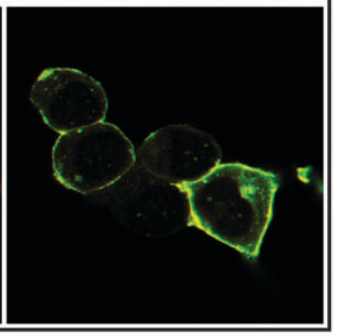

b

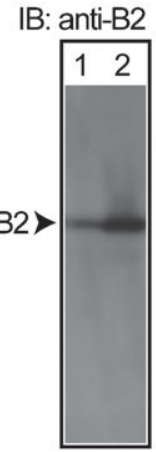

AP:anti-AT1 - +

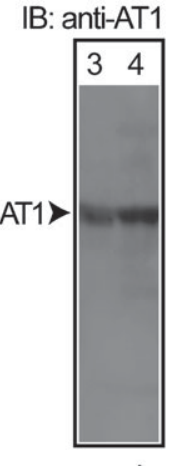

$-+$

Fig. 5 In vivo expansion of HEK293 cells in NOD.Scid mice enhances $\mathrm{AT}_{\mathbf{1}} / \mathbf{B}_{\mathbf{2}}$ receptor heterodimerization. (a) Immunofluorescence detection of the $\mathrm{B}_{2}$ receptor with rabbit anti- $\mathrm{B}_{2}$ receptor antibodies and Alexa Fluor 488-labeled secondary antibodies (left panel; anti-B2), and AT ${ }_{1}$ receptor with rat anti-AT $\mathrm{AT}_{1}$ receptor antibodies and Alexa Fluor 546-labeled secondary antibodies (middle panel; anti-AT1) revealed co-localization of $\mathrm{AT}_{1}$ and $\mathrm{B}_{2}$ receptors (right panel; Colocalization $\mathrm{AT} 1 / \mathrm{B} 2$ ) on dispersed HEK-AT $\mathrm{B}_{2}$ cells isolated after in vivo expansion for three weeks in NOD.Scid mice (original magnification, $630 \times$ ). (b) Immunoblot detection of the $\mathrm{B}_{2}$ receptor (IB: anti-B2; lanes 1,2), and $\mathrm{AT}_{1}$ receptor (IB: anti-AT1; lanes 3,4) was performed with solubilized $\mathrm{AT}_{1} / \mathrm{B}_{2}$ receptor expressing HEK-AT1/B2 cells expanded for three weeks in NOD.Scid mice (lanes 1,3). In lane 2, the $\mathrm{B}_{2}$ receptor co-enriched with $\mathrm{AT}_{1}$ receptor-specific antibodies ( $\pm \mathrm{AP}$ : anti-AT1) was detected in immunoblot with $\mathrm{F}(\mathrm{ab})_{2}$ fragments of affinity-purified anti- $\mathrm{B}_{2}$ receptor antibodies pre-absorbed to human proteins. As a control, the immunoaffinity-enriched $\mathrm{AT}_{1}$ receptor was detected in immunoblot with anti- $\mathrm{AT}_{1}$ antibodies (lane 4).

the novel system enabled the study of protein maturation, heterodimerization and function of an important cardiovascular receptor system with transfected cells under in vivo conditions.

\section{Discussion}

Hyperactivity of the angiotensin II $\mathrm{AT}_{1}$ receptor is a common feature of cardiovascular disease. ${ }^{1}$ Cellular mechanisms accounting for $\mathrm{AT}_{1}$ receptor sensitization in vivo are therefore of major interest regarding the pathogenesis and therapeutic concepts of cardiovascular disorders. Heterodimerization of the angiotensin $\mathrm{AT}_{1}$ receptor with the bradykinin $\mathrm{B}_{2}$ receptor leads to sensitization of the angiotensin II response in individuals with cardiovascular risk factors. ${ }^{3-5}$ Sensitization of the angiotensin II response relies on the formation of covalently stabilized receptor protein complexes, which provide a kinetically favoured platform for interaction with intracellular signalling molecules relative to dissociable receptors. ${ }^{6,7}$ 


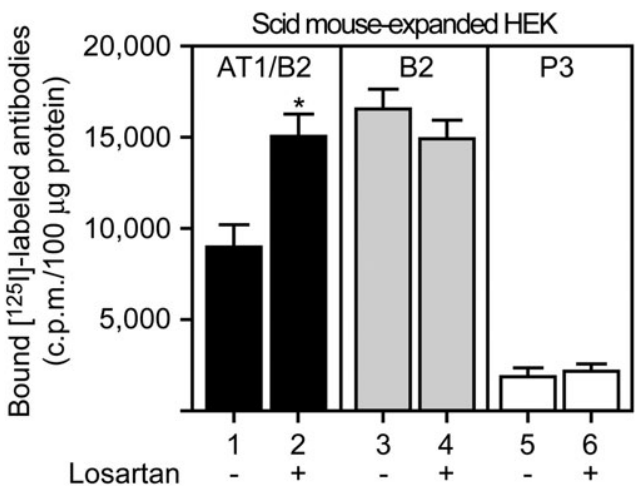

Fig. 6 Assessment of $A T_{1} / B_{2}$ receptor function in vivo by drug treatment with the $\mathbf{A T}_{\mathbf{1}}$-specific antagonist losartan. The functional coupling of $\mathrm{AT}_{1} / \mathrm{B}_{2}$ receptor heterodimers of in vivo expanded cells was assessed by the sensitivity to angiotensin II stimulation. In vivo stimulation of $\mathrm{AT}_{1} / \mathrm{B}_{2}$ receptors by circulating angiotensin II was analyzed by $\mathrm{B}_{2}$ receptor quantification of cells expanded in NOD.Scid mice and treated with or without the $\mathrm{AT}_{1}$-specific antagonist losartan. $\mathrm{B}_{2}$ receptors were quantified with $\left[{ }^{125} \mathrm{I}\right]$-labeled $\mathrm{F}(\mathrm{ab})_{2}$ fragments of affinity-purified anti- $\mathrm{B}_{2}$ receptor antibodies $(1 \mu \mathrm{Ci} /$ point; final concentration $5 \times 10^{-8} \mathrm{M}$ ) on dispersed NOD.Scid mouse-expanded HEK cells expressing either $\mathrm{AT}_{1} / \mathrm{B}_{2}$ (columns 1,2 ; AT1/B2) or $\mathrm{B}_{2}$ receptor only (columns 3,4; $\mathrm{B} 2$ ). As a control, the binding assay was performed with in vivo expanded HEK-P3 cells without $\mathrm{B}_{2}$ receptor expression (columns 5,6; P3). HEK cells were isolated after in vivo expansion in NOD.Scid mice treated without $(-)$ or with $(+)$ losartan for three weeks $\left(30 \mathrm{mg} \mathrm{kg}^{-1}\right)$ as indicated. Three individual experiments were done in triplicate each. The data represent mean \pm S.E., ${ }^{*}, P<0.03$.

However, factors, which account for the formation of covalently associated $\mathrm{AT}_{1} / \mathrm{B}_{2}$ receptor heterodimers are still not clear. Several groups showed that heterodimerization of the $\mathrm{B}_{2}$ receptor with the angiotensin II $\mathrm{AT}_{1}$ receptor or the closely related $\mathrm{AT}_{2}$ receptor is very effective in a native environment. $^{2-6,17}$ In contrast, under in vitro conditions, $\mathrm{B}_{2}$ receptor maturation and heterodimerization can be severely affected by chosen cell and culture conditions, which may disturb the fine-tuned equilibrium of the general chaperone system. ${ }^{10,18}$

In view of the pathophysiological importance of $\mathrm{AT}_{1} / \mathrm{B}_{2}$ receptor heterodimers, we sought to establish a cell system, which enables to study that important cardiovascular receptor system in a physiological environment. Cultured human embryonic kidney (HEK) cells were implanted subcutaneously into immunodeficient NOD.Scid mice, and expanded in the well-controlled physiological environment of mice. We chose HEK cells because several scientific facts make human embryonic kidney cells a suitable cell line for the functional study of cardiovascular targets, and specifically the angiotensin II $\mathrm{AT}_{1}$ receptor. (I) Kidney cell damage is a common feature of many cardiovascular disorders, e.g. hypertension, atherosclerosis, diabetes, heart failure. ${ }^{19-21}$ (II) Renal cell damage is induced by $\mathrm{AT}_{1}$ receptor stimulation and excessive angiotensin II release in the course of cardiovascular disease. ${ }^{22}$ (III) Microarray gene expression data showed renal epithelial, glomerular, and podocyte markers indicative of the embryonic, renal phenotype of in vivo expanded HEK cells. In view of the causal relationship between cardiovascular disease, renal cell destruction and the angiotensin II system as a major player, the human embryonic kidney cell (HEK) is capable of revealing important aspects of angiotensin-related effects on cardiovascular disease-induced organ cell damage.

Microarray analysis was used to validate the novel in vivo system. Microarray gene expression profiling revealed that the expansion of HEK cells for three weeks in vivo in immunodeficient NOD.Scid mice affected only a small subset of chaperones while leaving the general glucose-sensitive chaperone system largely unaltered. Notably, there was a major enhancement of calreticulin expression in NOD.Scid-expanded cells relative to conventional cell culture. Thus, the in vivo model seemed to restore an imbalance of the general chaperone system induced by conventional cell culture conditions.

Calreticulin is an indispensable chaperone, ${ }^{23,24}$ and maturation of the $B_{2}$ receptor protein relies on calreticulin. ${ }^{10,14}$ In agreement with the importance of calreticulin for the $B_{2}$ receptor protein, the maturation of $\mathrm{B}_{2}$ was strongly enhanced in the novel system. RNA interference revealed a causal relationship between calreticulin expression and enhanced $B_{2}$ receptor maturation. Concomitantly to the enhanced protein maturation, interaction of the $\mathrm{B}_{2}$ receptor with $\mathrm{AT}_{1}$ was strongly supported in the novel in vivo system as demonstrated by immunofluorescence and co-enrichment studies. The $\mathrm{AT}_{1} / \mathrm{B}_{2}$ receptor heterodimers synthesized in HEK cells under in vivo conditions were also functionally active, stimulated and co-internalized by circulating angiotensin II because treatment of NOD.Scid mice with the $\mathrm{AT}_{1}$-specific antagonist, losartan, substantially increased the number of $\mathrm{B}_{2}$ receptors on expanded HEK293 cells with $\mathrm{AT}_{1} / \mathrm{B}_{2}$ heterodimers. Thus, the newly established system enables the study of protein maturation and function under in vivo conditions.

In addition to the functional analysis of an important cardiovascular receptor system, our experiments provide strong evidence that the established model is also suitable to study the effect of drug action under in vivo conditions in general. During cell expansion, the transplanted cells seem to be effectively connected to the vascular system of NOD.Scid mice. As a consequence, a prototypic cardiovascular drugsuch as losartan-supplied in drinking water to NOD.Scid mice could gain access to the proteins of expanded HEK293 cells.

\section{Conclusions}

Our study established a novel model to analyze the function of proteins under in vivo conditions by applying immunodeficient NOD.Scid mice for in vivo expansion of cells. Using the model we studied $\mathrm{AT}_{1} / \mathrm{B}_{2}$ receptor heterodimers, which is an important cardiovascular receptor system and contributes to an exaggerated angiotensin II response in individuals with cardiovascular disease. With the novel model, we show that efficient $\mathrm{B}_{2}$ receptor maturation is a prerequisite for heterodimerization with the angiotensin $\mathrm{II} \mathrm{AT}_{1}$ receptor under in vivo conditions. Validation of the system by microarray gene expression profiling revealed restoration of an imbalanced chaperone system in the novel in vivo cell expansion model relative to conventional cell culture. The model also proved suitable for the study of drug action under in vivo conditions as exemplified with a widely used cardiovascular drug, i.e. losartan. 


\section{Acknowledgements}

The work was supported in part by the Swiss National Science Foundation.

\section{References}

1 U. Quitterer, H. Lother and S. Abdalla, Semin. Nephrol., 2004, 24, 115-119.

2 D. R. Fior, P. B. Hedlund and K. Fuxe, Neurosci. Lett., 1993, 163, 58-62.

3 S. AbdAlla, H. Lother and U. Quitterer, Nature, 2000, 407, 94-98.

4 S. AbdAlla, H. Lother, A. el Massiery and U. Quitterer, Nat. Med., 2001, 7, 1003-1009.

5 S. AbdAlla, A. Abdel-Baset, H. Lother, A. el Massiery and U. Quitterer, J. Mol. Neurosci., 2005, 26, 185-192.

6 L. F. Agnati, S. Ferré, C. Lluis, R. Franco and K. Fuxe, Pharmacol. Rev., 2003, 55(3), 509-550.

7 S. AbdAlla, H. Lother, A. Langer, Y. el Faramawy and U. Quitterer, Cell, 2004, 119, 343-354.

8 H. M. Sadeghi, G. Innamorati and M. Birnbaumer, J. Recept. Signal Transduct. Res., 1997, 17(1-3), 433-445.

9 R. D. Smith, A. J. Baukal, A. Zolyomi, Z. Gaborik, L. Hunyady, L. Sun, M. Zhang, H. C. Chen and K. J. Catt, Mol. Endocrinol., 1998, 12(5), 634-644.

10 J. Abd Alla, K. Reeck, A. Langer, T. Streichert and U. Quitterer, Biochem. Biophys. Res. Commun., 2009, 387, 186-190.

11 S. AbdAlla, H. Lother, A. el Missiry, A. Langer, P. Sergeev, Y. el Faramawy and U. Quitterer, J. Biol. Chem., 2009, 284, 6554-6565.
12 S. AbdAlla, H. Lother, A. el Missiry, P. Sergeev, A. Langer, Y. el Faramawy and U. Quitterer, J. Biol. Chem., 2009, 284, 6566-6574.

13 S. P. Ramachandra Rao, R. Wassell, M. A. Shaw and K. Sharma, Am. J. Physiol. Renal Physiol., 2007, 292, F1182-F1189.

14 K. Nakamura, A. Zuppini, S. Arnaudeau, J. Lynch, I. Ahsan, R. Krause, S. Papp, H. De Smedt, J. B. Parys, W. Muller-Esterl, D. P. Lew, K. H. Krause, N. Demaurex, M. Opas and M. Michalak, J. Cell Biol., 2001, 154, 961-972.

15 J. Hillion, M. Canals, M. Torvinen, V. Casado, R. Scott, A. Terasmaa, A. Hansson, S. Watson, M. E. Olah, J. Mallol, E. I. Canela, M. Zoli, L. F. Agnati, C. F. Ibanez, C. Lluis, R. Franco, S. Ferre and K. Fuxe, J. Biol. Chem., 2002, 277, 18091-18097.

16 T. Yamazaki, M. Tanimoto, T. Gohda, I. Ohara, S. Hagiwara, M. Murakoshi, M. Matsumoto, S. Kaneko, T. Aoki, H. Toyoda, Y. Ishikawa, K. Funabiki, S. Horikoshi and Y. Tomino, Nephron Exp. Nephrol., 2009, 113, e66-e76.

17 P. M. Abadir, A. Periasamy, R. M. Carey and H. M. Siragy, Hypertension, 2006, 48, 316-322.

18 J. A. Butz, R. T. Niebauer and A. S. Robinson, Biotechnol. Bioeng., 2003, 84, 292-304.

19 A. E. Cain and R. A. Khalil, Semin. Nephrol., 2002, 22, 3-13.

20 G. Deferrari, M. Ravera, L. Deferrari, S. Vettoretti, E. Ratto and D. Parodi, J. Am. Soc. Nephrol., 2002, 13, S224-S229.

21 M. E. Rea and M. E. Dunlap, Curr. Opin. Nephrol. Hypertens., 2008, 17, 87-92.

22 L. M. Ruilope, Curr. Med. Res. Opin., 2008, 24, 1285-1293.

23 N. Mesaeli, K. Nakamura, E. Zvaritch, P. Dickie, E. Dziak, K. H. Krause, M. Opas, D. H. MacLennan and M. Michalak, J. Cell Biol., 1999, 144, 857-868.

24 F. Rauch, J. Prud'homme, A. Arabian, S. Dedhar and R. St-Arnaud, Exp. Cell Res., 2000, 256, 105-111. 